\title{
STEM and Stuff
}

\section{Bruce Brasington}

Readers of Academic Questions are well aware of the humanities' parlous state in the Academy. STEM now reigns supreme even if, as Milton Ezrati argued recently in these pages, our "obsession" with it may well undermine its goals of scientific and technological innovation. ${ }^{1}$ As Ezrati also notes, we also should not be surprised by the general enthusiasm, for STEM is "a rerun of a show that played for years" since the launch of Sputnik. ${ }^{2}$ Perhaps we even could push its début further back, for STEM seems just the latest manifestation of a desire, almost libidinal, to render all education practical. Babbitt's bleating enthusiasm for "Business English" over Shakespeare and Latin rings just as fresh in 2021. I am certain he would have approved of engineering and technology, if not the rest of the acronym.

I hope as well that we agree with Ezrati that humanists can offer "perspectives that uncover applications that the STEM people miss.” ${ }^{3}$ I admit, however, that I am not optimistic these will be welcome. A comment from a long-departed administrator comes quickly to mind: "Well, we hired a medievalist because we knew you could teach lots of stuff.” If enrollments in history continue to decline, as they have since the "Great Recession” of 2008, soon there will be even less "stuff" alongside STEM. Again, this is nothing new. Back in 2003, British Education Secretary Charles Clark judged the teaching of medieval history a waste of taxpayers' money, though a few of us might be retained “for ornamental purposes.” I well remember colleagues being enraged. For my part, I was more mortified than angry. I had been reduced to a potted plant.

\footnotetext{
1 Milton Ezrati, "Our Dangerous Obsession with STEM," Academic Questions 33, no. 2 (Summer 2020): 307-313.

2 Ibid., 307.

3 Ibid., 312.
}

Bruce Brasington is Professor of History at the West Texas A \& M University; bbrasington@wtamu.edu. He has published two books, co-authored another, co-edited a volume of essays, and published over fifty scholarly articles and book chapters. Brasington is both a Regents Professor of the Texas A\&M University System and a Piper Foundation Professor. 
Nevertheless, what follows is an apology for that stuff or, more elegantly put by Russell Kirk, “cultural debris.” Our fractured culture cannot be healed simply by producing more engineers, scientists or, pace Babbitt, accountants. To that end, I suggest that we teachers of "stuff" are more essential than ever, not just by offering "diversity" but, more importantly, because we are dangerous. We challenge the optimistic, ${ }^{4}$ narrow worldview that STEM and vocational training are all we need.

By way of illustration, let me describe a particularly dangerous course I taught last fall. Like many history departments, we offer a senior "capstone" course at West Texas A\&M. In January, I had settled on what I hoped would be an interesting topic: "Disasters and Accidents: 1870-1914." Little did I know how relevant it would become by August. Throughout the semester, in class discussions and presentations of research, the students learned about epidemics of smallpox and yellow fever, mining explosions, collapsing bridges, sinking ships, structural fires. ${ }^{5}$ Time and time again, they confronted the hubris of experts who had assumed that both nature and human behavior had been rendered predictable and under control. They grew angry. I could not have been more pleased.

My students learned that dangerous, unpredictable variety lurked within what seemed to be the soundest bridge or carefully planned timetable. The more disasters they confronted, the more skeptical they grew toward technocrats, whether past or present, trusting that "facts," rightly interpreted with technical expertise, can always master the future. They came to appreciate, I believe, an enduring observation from Hayek that, despite advances in science and technology, our ignorance is neither decreasing nor are we closer to directing "all human activities.” ${ }^{6}$ Or, for that matter, the course of nature. ${ }^{7}$ Such a realization might be applied more generally to our fixation on STEM. For it seems often driven by the same uncritical confidence that all can be known, planned, controlled.

4 Perhaps what Richard Weaver once declared "hysterical optimism," on which see Roger Kimball, "The Consequences of Richard Weaver," The New Criterion (September 2006), https://newcriterion.com/issues/2006/9/the-consequences-of-richard-weaver.

5 For example the failure of the Tay River Bridge in Scotland in 1879, immortalized by the eccentric poet William McGonagall, and the Triangle Shirtwaist fire of 1911.

6 Friedrich Hayek, The Constitution of Liberty: The Definitive Edition, ed. Ronald Hamowy (Chicago: The University of Chicago Press, 2011), 77-78.

7 A particularly good example is the Quebec Bridge, which suddenly failed in 1907. Few public works projects in the early twentieth century appeared more expertly planned. Appearances were, of course, deceiving, on which see Eda Kranakis, "Fixing the Blame: Organizational Culture and the Quebec Bridge Collapse," Technology and Culture 43, no. 3 (2004): 487-518. 
The students also became dangerous because they could not avoid mortality, whether in seminar on in their daily lives. Granted, every historian, every history class, confronts the dead, but this encounter was especially immediate in the autumn of 2020. Loss and suffering were not remote, not confined to "history." From time to time, students were moved to speak of their own grief, loss, and anxiety. Their study and lived experience blended as an expression of reverence for the dead and how their "buried lives" spoke to the present. ${ }^{8}$

I do not think it an exaggeration to say that our seminar became an act of pietas. ${ }^{9}$ From those weeks of sharing historical tragedies and present miseries, pietas also provided hope. This was certainly not an optimism based on more information, more technology, more of anything. Collapsing bridges in Ohio and Quebec, theater fires in Chicago and New York, failed quarantines in New Orleans and Memphis had disposed of optimism early on. The surge in Covid cases by October did its part as well. No, hope emerged from the humble, often sad, study of the human experience. This hope is radical, for it proclaims that every life was extraordinary, is extraordinary. The dead matter. So do we. ${ }^{10}$ When historians and students confront that past and seek meaning for our present, we challenge with pietas the toxic pride that STEM and "Business English” are all we need. There has never been, and never well be, an ordinary human being. And that is the most dangerous stuff of all.

8 Paul Fussell, The Great War and Modern Memory (London and New York: Oxford University Press, 1975), 335.

9 Richard Weaver, Ideas Have Consequences (Chicago: University of Chicago Press, 2013), chapter 9. See also John P. East, "The Conservatism of Piety," https://theimaginativeconservative.org/2016/05/richard-weaver-conservatism-piety.html.

10 Eloquently elucidated by Tim O'Brien, The Things They Carried (New York: Broadway Books, 1998), $225-$ 246. The story of Linda figures in many of my classes. 